\title{
Dural sinus thrombosis in pediatric age
}

\author{
Trombose do seio dural em idade pediátrica
}

Filipe Mira Ferreira ${ }^{1}$, Bruno Lourenço Costa ${ }^{2}$, António Mendes ${ }^{1}$ Catarina Paiva ${ }^{3}$, António Roque Loureiro ${ }^{4}$

\begin{abstract}
Dural sinus thrombosis is a rare condition, usually results from a late complication of an infection of the paranasal sinuses. The signs and symptoms are extremely varied and nonspecific, being the diagnosis made through magnetic resonance imaging. Ten-year-old male patient that was sent to our emergency department with left endotropia and diplopia. Ophthalmic examination was performed and showed papilledema with margin blurred right and left eye, binocular diplopia and left eye endotropia. Visual acuity was 10/10 bilaterally. Given the suspected space occupying lesion of the central nervous system, the MRI was performed and confirmed the diagnosis of DST. For evaluating the intracranial pressure (IP), a lombar puncture (LP) with manometry was carried out and revealed IP of $20 \mathrm{mmHg}$ (normal values: $<15 \mathrm{mmHg}$ ). Towards this, the child's was admitted for medical treatment (low molecular weight enoxaparin subcutaneous $1,5 \mathrm{mg} / \mathrm{kg} /$ day $(60 \mathrm{mg} /$ day), prednisolone $35 \mathrm{mg} /$ per day and acetazolamide $250 \mathrm{mg} /$ per day) over 10 days. After 1 month of follow-up there was deterioration of the ophthalmologic condition. A new LP was made and showed IP of $40 \mathrm{mmHg}$ resilient to medical treatment. After multidisciplinary discussion of the case, it was decided for conducting lumboperitoneal shunt. The need for a great deal of suspicion for both the initial diagnosis and for monitoring complications make DST approach a special process.
\end{abstract}

Keywords: Sinus thrombosis, intracranial/diagnosis; Intracranial hypertension; Magnetic resonance imaging; Case reports

\section{RESUMO}

A trombose do seio dural é uma situação clínica rara, que resulta normalmente da complicação de processos infecciosos dos seios perinasais. Os sintomas e sinais são extremamente variados e inespecíficos sendo o diagnóstico feito através da ressonância magnética nuclear. Esse trabalho relata a ocorrência de trombose do seio dural em um paciente com idade pediátrica. Paciente com 10 anos de idade, sexo masculino, foi enviado ao serviço de urgência devido à diplopia e endotropia no olho esquerdo. No exame oftalmológico foi detectado papiledema bilateral, diplopia binocular e endotropia do olho esquerdo. Apresentava acuidade visual de 10/10 bilateralmente. Diante da suspeita de lesão ocupando espaço do sistema nervoso central, foi realizada ressonância magnética nuclear que confirmou o diagnóstico de TSD. Para avaliar a pressão intracraniana foi efetuada uma punção lombar com manometria, e esta demonstrou uma pressão intracraniana de $20 \mathrm{mmHg}$ (normal: $<15 \mathrm{mmHg}$ ). Perante isto a criança ficou internada para tratamento médico (enoxaparina de baixo peso molecular 1,5 $\mathrm{mg} / \mathrm{kg} /$ dia subcutâneo (60 mg/dia), prednisolona $35 \mathrm{mg} /$ dia oral e acetazolamida $250 \mathrm{mg} /$ dia oral) durante 10 dias. Após $1 \mathrm{mês}$ de followup verificou-se agravamento oftalmológico. A realização de nova punção lombar apresentou uma pressão intracraniana de $40 \mathrm{mmHg}$ que não cedia ao tratamento médico. Após discussão multidisciplinar do caso optou-se pela realização de derivação lombo-peritoneal. A necessidade de uma grande dose de suspeição clínica, tanto para o diagnóstico inicial quanto para a monitorização das complicações, tornam a abordagem da trombose do seio dural um processo singular.

Descritores: Trombose dos seios intracranianos/diagnóstico; Hipertensão intracraniana; Imagem por ressonância magnética; Relatos de casos

\footnotetext{
${ }^{1}$ Intern of the Ophthalmology Complementary Internship at the General Hospital of the Hospital and University Center of Coimbra, Coimbra, Portugal.

${ }^{2}$ Intern of the Neurosurgery Complementary Internship at the General Hospital of the Hospital and University Center of Coimbra, Coimbra, Portugal.

${ }^{3}$ Ophthalmology Hospital Assistant at the General Hospital of the Hospital and University Center of Coimbra, Coimbra, Portugal.

${ }^{4}$ Director of the Ophthalmology Service at the General Hospital of the Hospital and University Center of Coimbra, Coimbra, Portugal.
}

The authors declare have no conflict of interest

Received for publication 29/10/2012 - Accepted for publication 26/03/2014 


\section{INTRODUCTION}

D ural sinus thrombosis (DST) comprises the sagittal, transverse and sigmoid sinuses, and in about one third of the cases it comprises multiple sinuses ${ }^{(1,2)}$.

The estimated incidence of DST in pediatric age is approximately 0.67 per 100,000 children per year ${ }^{(3)}$.

TSD typically results from a complication of infectious processes of the paranasal sinuses and the middle ear, but there may be aseptic forms associated to predisposing medical conditions for thromboembolic events such as: haematological disorders, trauma, anemia and dehydration ${ }^{(3-5)}$.

The clinical presentation is nonspecific and may manifest as coma, headaches, vomiting, lethargy with ocular paresis and diplopia, which often leads to a late diagnosis.

The diagnosis is made by nuclear magnetic resonance (NMR) alone or in association with cerebral angiography ${ }^{(6)}$. This paper reports the case of occurrence of DST in a pediatric patient.

\section{Case Report}

A 10-year old male patient is sent to the emergency room due to endothropy of the left eye (LE) and binocular diplopia. As relevant systemic background there was a flu syndrome since 1 month before, and binocular diplopia with a development of about fifteen days.

The ophthalmological exam showed intermittent binocular diplopia, endothropy of the left eye of about $15^{\circ}$ (Hirschberg Method) and limitation of abduction in levoversion of the LE. It presented best visual acuity (VA) corrected bilaterally of 10/10. Biomicroscopy without changes. Goldmann applanation tonometry: $12 \mathrm{mmHg}$ in both eyes, and in fundoscopic observation: optical discs with undefined boundaries in both eyes by exuberant bilateral papilledema. Macular regions were normal in both eyes (Figure 1).

The decision was to perform a retinal fluorescein

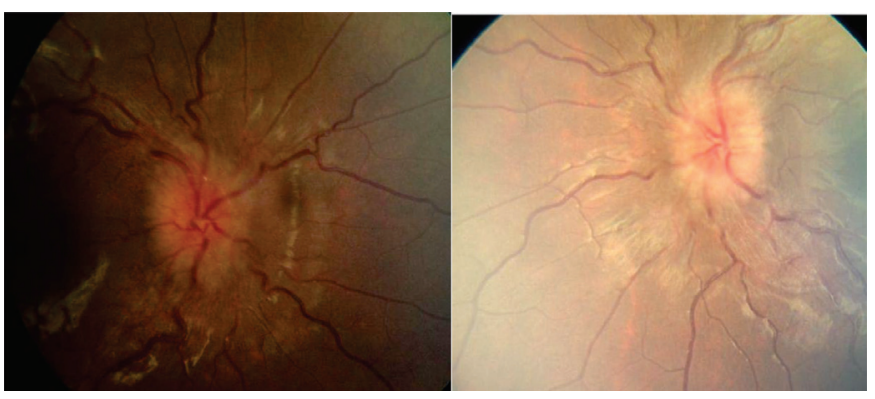

Figure 1. Retinography

angiography which showed late hyperfluorescence with dye leak in both eyes.

An MRI was performed in association with the cerebral angiography (Figure 2) which revealed: exclusion, in the venous study, of all the right sigmoid sinus, the distal portion of the transverse sinus and the proximal segment of the internal jugular vein, which is followed by isosignal on $\mathrm{T} 1$ and a discrete hypersignal on the remaining ponderations, and after the use of contrast an enhancement that is predominantly peripheral was

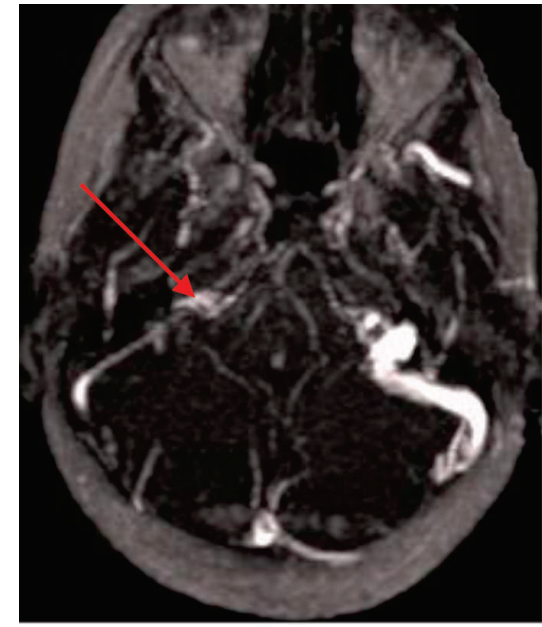

Figure 2: NMR angiography - subtraction image within the right sigmoid sinus

observed. The expansion of the optic nerve sheath is also observed. These aspects are suggestive of venous thrombosis.

Given the suspicion of DST, the decision was to request the Neurology to observe, and no neurological disorders were detected. Nevertheless, a lumbar puncture was performed and the result revealed an intracranial pressure (PIC) of $20 \mathrm{mmHg}$.

Before the clinical profile, the child was hospitalized for medical treatment with low molecular weight enoxaparin 1.5 $\mathrm{mg} / \mathrm{kg} /$ day subcutaneously (60 mg/day), prednisolone $35 \mathrm{mg} /$ day orally and acetazolamide $250 \mathrm{mg} /$ day orally.

During hospitalization the tests of blood count, biochemistry, microbiology, serology, a study of prothrombotic factors, autoimmunity and a study of the cerebrospinal fluid (CSF) were performed.

The child was discharged after ten days of hospitalization, with no complaints, treated with enoxaparin $60 \mathrm{mg} /$ day and a regressive scheme of oral corticosteroids. The follow-up was performed at the end of 1 month and showed:VA RE: 4/10 and VA LE: $1 / 10$. In the fundoscopy: less exuberant papilledema, but associated with bilateral pallor of the optic disc. The performance of a control NMR showed a profile similar to the previous one. The performance of visual fields showed severe bilateral loss of the visual field, more intense in the LE, with preservation of central islands of vision (Figure 3).Further evaluation has been requested by the Neurology, and a new lumbar puncture was performed with manometry, whose result revealed PIC of $40 \mathrm{mmHg}$. The clinical case was then discussed with the Neurosurgery which indicated external lumbar drainage with monitoring of the CSF pressure by continuous manometry. Despite the decrease in the PIC, the decision was to have a lumboperitoneal shunt. The child was discharged after 48 hours, with no complaints, PIC between 8$12 \mathrm{mmHg}$ and decreased bilateral papilledema.

After 1 month, the child was asymptomatic and with the following eye exam results: VA RE: 9/10 and VA LE: 5/10. The funduscopy showed an improvement of the edema of the optic disc, however associated to pallor in the RE and optic atrophy in LE (Figure 4). The performance of new visual fields showed am improvement (Figure 5). 

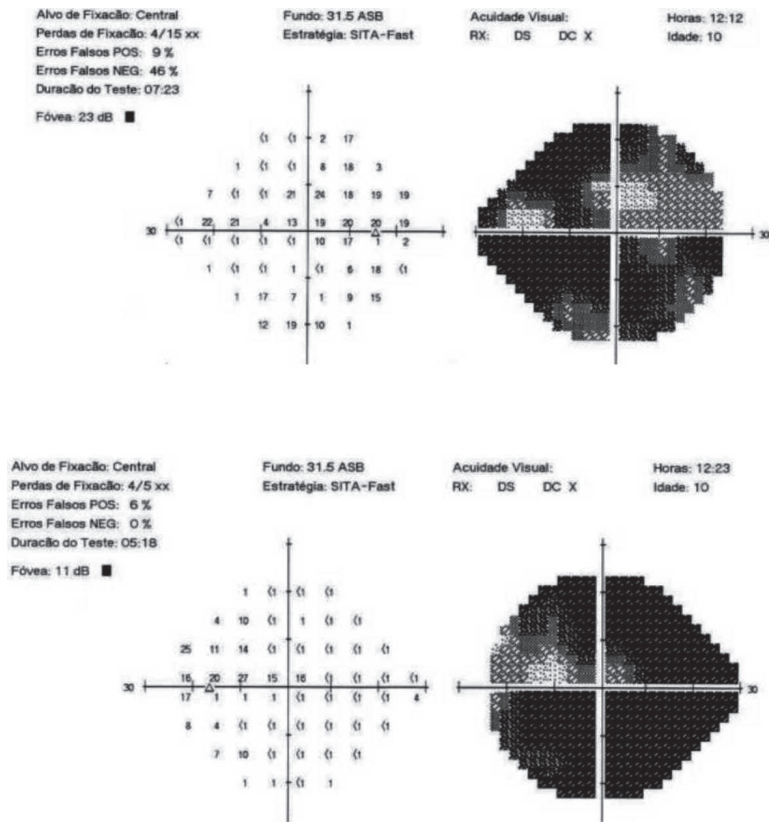

Figure 3: Visual field 24-2 SITA Fast
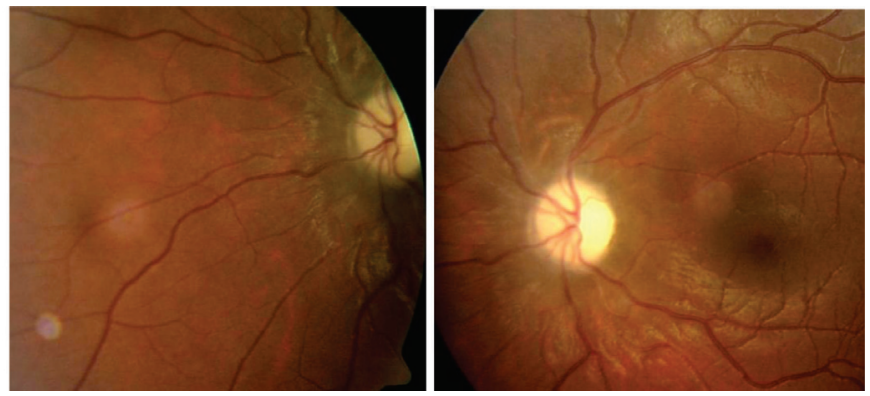

Figure 4: Retinography RLE

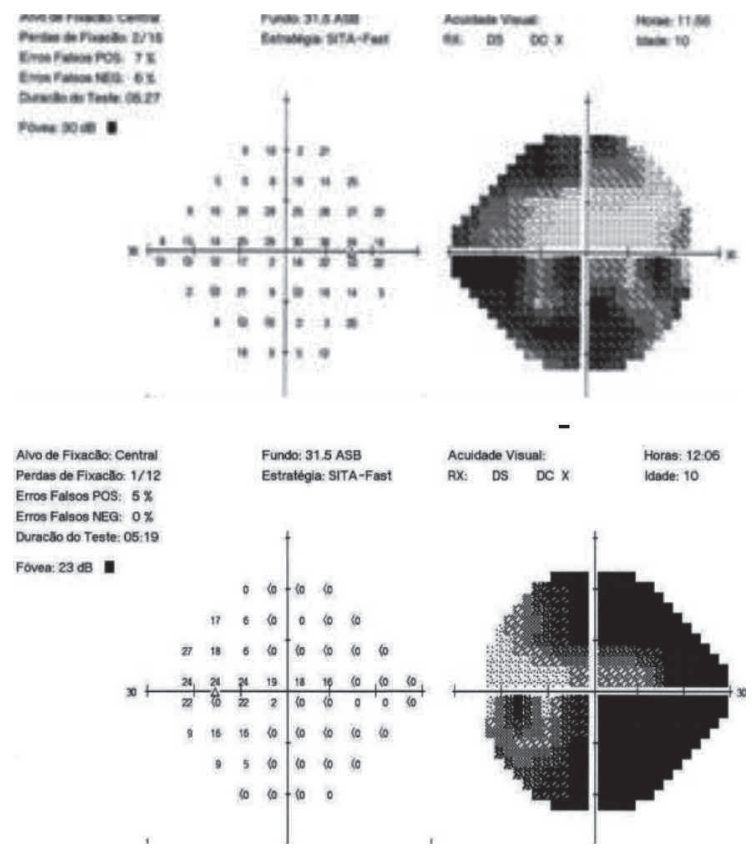

Figure 5: Visual field RLE 24-2 SITA Fast

\section{Discussion}

The DST usually involves the sagittal, transverse and sigmoid sinuses, showing an incidence of 0.67 cases per 100,000 children per year ${ }^{(3)}$.

The clinical presentation is nonspecific, often leading to a late diagnosis or even to its omission. Symptoms can range from headache, decreased VA, diplopia to lethargy, coma and death, having Sébire et al. ${ }^{(7)}$ concluded that headaches, fever and changes of the cranial nerves were the most common form of presentation.

This clinical situation typically results from infectious processes of the paranasal sinuses or prothrombotic conditions, being acquired such as anemia and dehydration, or genetic such as increased factor VIII, increased fibrinogen, decreased proteins $\mathrm{C}$ and $\mathrm{S}$, factor $\mathrm{V}$ Leiden mutation, homozygosity of thermolabile gene variant of methylenetetrahydrofolate reductase ( $t$ MTHFR). In the same study of Sébire et al. ${ }^{(7)}$, anemia and increased factor VIII were the most commonly found laboratory findings. In about $25 \%$ of the cases there is no predisposing factor identified ${ }^{(8)}$.

In the present clinical case, a comprehensive study of infectious causes was performed by serology to screen adenovirus, mycoplasma, pneumonia, cytomegalovirus, herpes simplex 1 and 2, Epstein-Barr virus, and all the results were negative. Blood cultures for anaerobic, aerobic and fungi also presented negative results. The research of prothrombotic risk factors including fibrinogen, protein $\mathrm{C}$ and $\mathrm{S}$, anti-thrombin, anti-cardiolipin, lupus anticoagulant, plasminogen, homocysteine, prothrombin, factor V Leiden, homozygosity for t-MTHFR, factor VIII and factor XII have all had negative results.

Electrocardiogram, echocardiogram, carotid Doppler were also performed - all without changes.

Given the results of the supplementary diagnostic exams performed, it was concluded that this is an idiopathic condition, fitting in the $25 \%$ of cases without an etiologic diagnosis. It could also be supposed that the flu-like illness occurred a month before has triggered the current situation, but there is no clinical data to prove this relationship. There is some controversy regarding the use of enoxaparin, but several studies have shown that its use is associated with a decreased mortality and an increased recovery rate ro,10). $^{(9)}$

The diagnosis of DST requires a large initial clinical suspicion, and the confirmation is established through the use of NMR angiography (6). This method allows the identification of the thrombus and the involved sinus completing deficit, currently being considered as the gold standard.

The incidence of intracranial hypertension arises in the work of Sébire et al. in $62 \%$ of cases, yet the convulsions and the appearance of new thrombotic events are the most frequent complications $^{(7)}$. As there was no initial response to the medical therapy and there was a worsening of PIC, there was a need for neurosurgical therapy with the placement of lumboperitoneal shunt.

Permanent complications such as blindness and focal neurological deficits are described in about $6-20 \%$ of the ca$\operatorname{ses}^{(1,11,12)}$, and a mortality rate between 4.3 and $30 \%$. The prognosis seems to be related to the extent and location of the parenchymal lesion, hemoglobin level, age, and most likely the rapid diagnosis and treatment. 


\section{Conclusion}

The dural sinus thrombosis is a rare but fatal clinical situation in some cases. Often the ophthalmologist becomes the key element both in the diagnosis and monitoring of these patients, therefore being important to alert the ophthalmic community to its importance.

\section{ReferenCes}

1. Stam J. Thrombosis of the cerebral veins and sinuses. N Eng J Med. 2005;352(17):1791-8. Comment in N Engl J Med. 2005;353 (3):314-5.

2. Renowden S. Cerebral venous sinus thrombosis. Eur Radiol. 2004;14(2):215-26. Review.

3. deVeber G, Andrew M, Adams C, Bjornson B, Booth F, Buckley DJ, Camfield CS, David M, Humphreys P, Langevin P, MacDonald EA, Gillett J, Meaney B, Shevell M, Sinclair DB, Yager J; Canadian Pediatric Ischemic Stroke Study Group. Cerebral sinovenous thrombosis in children. N Eng J Med. 2001;345(6):417-23. Comment in $N$ Engl J Med. 2001;345(24):1777-8.

4. Carvalho KS, Bodensteiner JB, Connolly PJ, Garg BP. Cerebral venous thrombosis in children. J Child Neurol. 2001;16(8):574-80.

5. Heller C, Heinecke A, Junker R, Knöfler R, Kosch A, Kurnik K, Schobess R, von Eckardstein A, Sträter R, Zieger B, NowakGöttl U; Childhood Stroke Study Group. Cerebral venous thrombosis in children: a multifactorial origin. Circulation. 2003;108(11):1362-7.
6. Medlock MD, Olivero WC, Hanigan WC, Wright RM, Winek SJ. Children with cerebral venous sinus thrombosis diagnosed with magnetic resonance imaging and magnetic resonance angiography. Neurosurgery. 1992;31(5):870-6; discussion 876.

7. Sébire G, Tabarki B, Saunders DE, Leroy I, Liesner R, Saint-Martin $\mathrm{C}$, et al. Cerebral venous sinus thrombosis in children: risk factors, presentation, diagnosis and outcome. Brain. 2005;128(Pt 3):477-89.

8. Bousser MG, Barnett HJM. Cerebral venous thrombosis. In: Barnett HJ, editor. Stroke: pathophysiology, diagnosis and management. 2nd ed. New York: Churchill Livingstone; 1992.

9. Einhäulpl KM, Villringer A, Meister W, Mehraein S, Garner C, Pellkofer M, et al. Heparin treatment in sinus venous thrombosis. Lancet.1991;338(8767):597-600. Erratum in Lancet. 1991;338 (8772):958. Comment in Lancet. 1991;338(8775):1154.

10. Stam J, de Bruijn S, deVeber G. Anticoagulation for cerebral sinus thrombosis. Stroke. 2003;34(4):1054-5.

11. Ferro JM, Canhão P, Stam J, Bousser MG, Barinagarrementeria F; ISCVT Investigators. Prognosis of cerebral vein and dural sinus thrombosis: results of the International Study on Cerebral Vein and Dural Sinus Thrombosis (ISCVT). Stroke. 2004;35(3):664-70.

12. Stolz E, Trittmacher S, Rahimi A Gerriets T, Röttger C, Siekmann $\mathrm{R}$, et al. Influence of recanalization on outcome in dural sinus thrombosis: a prospective study. Stroke. 2004;35(2):544-7.

\section{Corresponding author:}

Filipe Mira Ferreira

E-mail: filipemiraferreira@gmail.com 